\title{
The Effect of Material Weakness Disclosure on Investment Judgment
}

\author{
Luciana Spica Almilia ${ }^{1}$, Nurul Hasanah Uswati Dewi ${ }^{2}$, Putri Wulanditya ${ }^{3}$ \\ $\left\{\right.$ lucy@perbanas.ac.id ${ }^{1}$,nurul@perbanas.ac.id ${ }^{2}$,putri@perbanas.ac.id $\left.{ }^{3}\right\}$ \\ STIE PERBANAS Surabaya, Jl. Nginden Semolo No.34-36, Ngenden Jangkungan, Sukolilo, Surabaya, \\ Jawa Timur, Indonesia $60118^{1,2,3}$
}

\begin{abstract}
In Indonesia, financial information is information that is most needed by investors or shareholders. One form of financial information needed by investors is information about the company's ability to generate profits. Based on this information show that the role of information on internal control is not important in investment decision making. This paper examines decision making by nonprofessional investors regarding the risks associated with auditing and the risk of disclosure weaknesses associated with auditing. This study uses an experimental method (in subjects). Respondents are undergraduate students at private universities. Participants were asked to evaluate the company's attractiveness. In manipulating the types of material weaknesses, participants analyze 2 types of material weaknesses including entity level material weaknesses and account specific material weaknesses. The results of this study reveal that there are different responses in analyzing entity level material weaknesses and account specific material weaknesses. Furthermore, a direct effect exist between types of material weaknesses and financial reporting risks mediated by risks that are not audit related and risks related to audit.
\end{abstract}

Keywords: material weakness, investment judgment, entity level material weakness, accountspecific material weakness.

\section{Introduction}

Good corporate governance is one of the attractions of investors, besides that it can also attract creditors to lend funds to companies. However there is no guarantee that every company that applies the principles of good corporate governance will avoid mistakes and failures. Factors that can be considered in implementing Good Corporate Governance (GCG) consist of external and internal factors. In order to have effective usage of good corporate governance practices, internal factors are the key drivers of the originating from within the company. One of the question to be asked in the internal factor is: Is there an effective internal control system to avoid any conceivable inconsistencies in the company?

In purpose to form solid and secure operating activities, the internal control system manages and controls risks properly includes all policies and procedures in all working activities to protect company's assets. To achieve the functional effectiveness and efficiency, the internal controls is applied to support the operationalization. A vigorous internal control system is intended to achieve planned performance goals, intensify confidence for management, and promote compliance through tide regulations and risk mitigation.

Internal control can provide a reliable basis for investors and potential investors to assess investment performance and management. In Indonesia, financial information that is most needed by investors or shareholders. One form of financial information needed by investors is information about the company's ability to generate profits. This information is provided by the Accounting field. Financial information is a company financial information that shows profit or loss in one accounting period. This financial information is useful for shareholders or investors to make decisions to buy shares or invest in one company or provide capital loans supported by bonds. Without financial information, investors will not invest their capital and entrepreneurs will lose capital from investors. By looking at the financial statements, everyone can know what is done by the company, including the occurrence of fraud. This financial information is made as proof of accountability to the owners of capital or investors, so investors know where their money is being used.

Based on the information above shows that the role of information on internal control is not important in investment decisions making for investors in Indonesia. This is different in other countries, for example the United States that information related to internal control can also affect investors in 
making investment decisions. If there is weakness in the balance sheet in the client's Internal control over financial reporting (ICOFR), the auditors are required to issue and report them. The disclosure of this information in an adverse report describes the nature of the control deficiency and the likelihood that the control deficiency fails to prevent or detect material misstatement in the financial report. (Asare and Wright, 2012a).

\section{Literature Review}

\subsection{Investment Decision Making}

Some studies examine the factors that influence investment decision making. Hogart and Einhorn (1992) develop a model related to investment decision making namely the Belief Adjustment Model. This model denotes that decision makers often fall into irrational decisions.

The second study works on the overconfident and experience on the increasing or reducing the information order effect in investment decion making. Almilia and Wulanditya (2016) assert that person with an overwhelm confidence tends to neglect the circulate information, and this excessive confidence will affect the loading of information.

The third study attempts to combine the belief adjustment model with the investment decision frame on the investment decision making. Almilia et al. (2018) show that respondents provide different answers when receiving non-accounting information (expressive decision frameworks) with different presentation patterns, step by step and the final sequence. The other result that Almilia et al. (2018) found that there were similar responses between participants who received accountancy information (financial decision frame) and non-accountancy information (expressive decision frame) at the last sequence presentation format. Overall, the conducted study by Almilia et al. (2018) designate that Investment Decision Frame has an effects on the investment decision making, when the information presentation format is in chronological order.

The fourth study examines the task complexity, information technology utilization (interactive and visualization), information classification (pro forma earnings and profit information), and information pattern (graphs and texts). Dilla et al. (2013) state that amateur investor influence by graphic content information to make an investment decision, while the professional does not. Tang et al. (2014) revelaed that by providing a high levels of visualization information or high level of interaction alone may degrade the investment decision making performance. Ang and Trotman's work in 2015 describe that that if the investment decision is organized in groups, information comparison between quantitative and qualitative is preferred. In term of assignment acceptance with lower and higher complexity in decision making, there are significant differences in the average level of accuracy, level of confidence, and calibration levels stated by Almilia et al. (2019).

\subsection{Internal Control and Investment Decision Making}

The historical control model has changed in the section 404 (b) of SOX by requiring the auditor to prove and verify the effectiveness of their public client's ICOFR. ICOFR proposes to provide early warning signals to the stakeholders to assess the accuracy of financial information in the company's reporting system. When a material weakness found in company's internal controls over financial reporting (ICOFR), a report issues by the auditors that disclosure this information is required which also portrays the nature of control deficiency and the possibility that the control deficiency fails to uncover and inhibit material misstatements in the financial report. The purpose of this adverse report is for users' consideration regard to the reliability of the company's financial reporting system.

Asare and Wright (2012a) denotes that when entity-level material weaknesses occured, the assessment of equity analyst is similar with the reporting threshold regime regarding the possibility of future misstatements. Moreover for specific material weakness, the assessment of equity analysts which compare between reasonable possible condition and remote condition is significantly higher on probability material misstatement. The result of Asare and Wright work (2012a) revealed that entity-level material weaknesses create the same level of concern for potential future misstatements, whether reporting thresholds are more than remote or reasonably possible. As such, it is important to provide information to users about these material weaknesses, and if it is possible they will prevent or early detect material misstatement. 
Asare and Wright (2012b) suggest that it is necessary to conduct a Standard unqualified audit report (SAR) on financial statements that have lost credibility when combined with adverse entity level ICOFR reports as alleged by several users. These costs that were not previously recognized to the entitylevel ICOFR recipients are detrimental, because they have a negative impact on the investment appraisal of investors, providing another reason to avoid or correct material weaknesses in ICOFR. Arguably, this is also potentially dangerous for the audit profession because the diminished trust in SAR can eventually slide down the guarantee function..

Rice and Weber (2012) found that detection and disclosure incentives play a role in reporting material weaknesses found. The findings also indicate that the ICOFR report is not always effective in identifying and disclosing existing material weaknesses by asking whether the recent decrease in reported material weaknesses reflects improvements in underlying control practices. However, because of the design choices, it is unclear whether the results can be generalized to companies with material weaknesses that do not lead to restatement.

Literatures on auditors' evaluation, reporting, internal control over financial reporting (ICOFR), as required by the Sarbanes-Oxley Act were synthesized by Asare et al. (2013). The objectives of this work are as follow: firstly is information presentation on how well auditors perform the task, which serves as feedback to the Public Company Accounting Oversight Board on implementation issues and problems related to auditors' application of the professional standards on ICOFR; and secondly are gaps identification of existing literatures and promote fruitful areas for further research. In line with Auditing Standard No. 5, Asare et al. (2013) portray five stages of the ICOFR audit: (1) planning; (2) scoping; (3) testing; (4) evaluation; and (5) reporting. Moreover, they classify the determinants of performance into five broader areas namely: (a) the auditor's attributes, (b) the client's attributes, (c) the interaction between the auditor and the client, (d) task attributes, and (e) environmental attributes. By giving the ICOFR task taxonomy, proposing performance determinant models, evaluating the auditor's performance, underline findings and substantial gaps for regulators, and putting a milestone for research in the future are the key contributions in this study. Therefore, hypothesis to be examined towards the influence of material shortcomings formulated as follow:

H1: Subject who are receivied entity-level material weakness information will give difference judgment on finanial reporting risk assesment and non-audit related risk compared to Subject who are received account-specific material weakness information.

\section{Research Method}

An experimental study applied in this study by examining the causal relationship among variables in order to achieve the research objective. Some requirements for selected respondents are as follows: familiar with investment, capital market and financial statement analysis. The selected are students from accounting department who have taken the subject of Investment Management and Capital Markets and also Financial Statement Analysis subject.

Participant were asked to analyze a company's investment attractiveness. The given instrument provides general instruction, company's general information in order to complete the task. In the background information contained with auditor's unqualified report on the financial report. In purpose to attract more student participation and shorten the duration of experiment completion, this study provides summary of financial statement audit report. In order to manipulate the type of material shortcomings, this study provides more information on entity-level material weakness and account-specific material weakness in the part of summary audit report (the instruments from Asare and Wright, 2017 was modified).

Moreover, respondents were asked to presume that they were evaluating a company's common stock investment attractiveness in the first quarter and also assess the risks related to the material control weakness: remediation, operations, familiarity, information, and verification. Eventually, respondents conclude their overall risk assessment as suggested by the company's financial reports regarding to the auditor's adverse control report $(0=$ no financial reporting risk and $100=$ maximum financial reporting risk).. In the last stage, respondents After reading and examining the items provided, further analysis is carried out to examine the manipulation of questions, questions to measure participants' basic skills in the area of financial reporting and capital market analysis, and respondent demographic items.

Participants were divided into two assignment groups. The first group participants were asked to do assignments related to entity level weaknesses, after that they continued to do assignments related to 
account-specific material weaknesses. Participants in the second group were asked to do assignments related to account-specific material weaknesses after that followed by assignments related to entity level weaknesses. This research use an independent sample t test to examine the hypothesis.

\section{Results and Discussion}

Accountancy and management students are the respondents in this study who have knowledge in the field of investment and stock market and financial report analysis. A total of 137 students where 112 of them have passed the manipulation check and could be proceed to the hypothesis testing.

Table 1 presents the results of the participant testing in group 1, which is the group that receives assignment of entity level weaknesses, after that it does the assignment of account-specific weaknesses. The results show that there were differences in response to operational risk and financial reporting risk for participants who received assignment of entity-level material shortcoming compared to members who gotten account-specific shortcomings. The results show that the risk of financial reporting would be higher in companies that experienced account-specific material weaknesses compared to companies that experienced entity-level material weaknesses. The results of this study also indicate that there are differences between operational risks in companies that experience account specific material weaknesses and companies that experience entity-level material weaknesses.

Table 1. Descriptive Statistics and Univariate Test of Mean Difference (First Group)

\begin{tabular}{|c|c|c|c|c|}
\hline Variables & $\begin{array}{c}\text { Mean } \\
\text { Entity- } \\
\text { Level } \\
\text { Material } \\
\text { Weakness }\end{array}$ & $\begin{array}{c}\text { Mean } \\
\text { Account- } \\
\text { specific } \\
\text { Material } \\
\text { Weakness }\end{array}$ & t-test & p-value \\
\hline \multicolumn{5}{|l|}{ Remediation Risk } \\
\hline Costliness to fix & 71,0204 & 72,8163 & $-0,414$ & 0,680 \\
\hline Difficulty to fix & 69,0408 & 71,6735 & $-0,568$ & 0,572 \\
\hline \multicolumn{5}{|l|}{ Operational Risk } \\
\hline Management effectiveness & 50,4694 & 40,6735 & 1,868 & 0,065 \\
\hline Impact on operations and profitability & 72,1224 & 80,4286 & $-2,097$ & 0,039 \\
\hline Impact on future cash flows & 69,1020 & 78,4082 & $-2,138$ & 0,035 \\
\hline \multicolumn{5}{|l|}{ Familiarity Risk } \\
\hline Familiarity with material shortcomings & 67,3265 & 70,4694 & $-0,732$ & 0,466 \\
\hline $\begin{array}{l}\text { To what extent risk is understood by } \\
\text { management }\end{array}$ & 67,0204 & 65,7551 & 0,265 & 0,792 \\
\hline $\begin{array}{l}\text { To what extent risk is known by } \\
\text { management }\end{array}$ & 60,9796 & 52,6367 & 1,379 & 0,171 \\
\hline Immediacy of risk & 49,0612 & 54,8980 & $-0,991$ & 0,324 \\
\hline $\begin{array}{l}\text { Extent to which it is difficult for } \\
\text { management to control risk }\end{array}$ & 58,9796 & 638980 & $-0,961$ & 0,339 \\
\hline \multicolumn{5}{|l|}{ Information Risk } \\
\hline $\begin{array}{l}\text { Likelihood of current year material } \\
\text { misstatement }\end{array}$ & 72,8776 & 77,0000 & $-0,898$ & 0,371 \\
\hline Magnitude of misstatement & 35,5714 & 46,1837 & $-1,582$ & 0,117 \\
\hline Likelihood next year is misstated & 58,6939 & 62,4490 & $-0,657$ & 0,513 \\
\hline \multicolumn{5}{|l|}{ Verification Risk } \\
\hline $\begin{array}{l}\text { Confidence that auditor will detect } \\
\text { misstatements present }\end{array}$ & 79,4082 & 79,8367 & $-0,103$ & 0,918 \\
\hline $\begin{array}{l}\text { To what Extent risk is known by } \\
\text { Auditor }\end{array}$ & 71,0408 & 78,6122 & $-1,676$ & 0,097 \\
\hline Financial Reporting Risk & 71,2041 & 80,7447 & $-2,354$ & 0,021 \\
\hline
\end{tabular}

Table 2 presents the results of participant testing in group 2, namely the group that received the assignment of account-specific weaknesses, after which they received the assignment of entity level shortcomings. The revealed result in the group 2 shows different results. The result implies that 
operational risks related to management effectiveness would be higher in companies that experienced entity-level material weakness compared to companies that experienced account-specific material shortcomings.

Table 2. Statistical Descriptive and Univariate Test of Mean Difference (Second Group)

\begin{tabular}{|c|c|c|c|c|}
\hline Variables & $\begin{array}{c}\text { Mean } \\
\text { Entity- } \\
\text { Level } \\
\text { Material } \\
\text { Weakness }\end{array}$ & $\begin{array}{c}\text { Mean } \\
\text { Account- } \\
\text { specific } \\
\text { Material } \\
\text { Weakness }\end{array}$ & t-test & p-value \\
\hline \multicolumn{5}{|l|}{ Remediation Risk } \\
\hline Costliness to fix & 66,1429 & 66,7302 & $-0,130$ & 0,897 \\
\hline Difficulty to fix & 61,5714 & 65,3810 & $-0,830$ & 0,408 \\
\hline \multicolumn{5}{|l|}{ Operational Risk } \\
\hline Management effectiveness & 52,3333 & 44,0794 & 1,790 & 0,076 \\
\hline Impact on operations and profitability & 69,7619 & 68,5873 & 0,278 & 0,782 \\
\hline Impact on future cash flows & 70,7460 & 70,6984 & 0,012 & 0,991 \\
\hline \multicolumn{5}{|l|}{ Familiarity Risk } \\
\hline \begin{tabular}{l|l} 
& Familiarity with material shortcomings
\end{tabular} & 66,5397 & 69,8571 & $-0,917$ & 0,361 \\
\hline $\begin{array}{l}\text { To what extent risk is understood by } \\
\text { management }\end{array}$ & 65,2857 & 67,9206 & $-0,662$ & 0,509 \\
\hline $\begin{array}{l}\text { To what extent risk is known by } \\
\text { management }\end{array}$ & 60,3175 & 57,9841 & 0,445 & 0,657 \\
\hline Risk Immediacy & 62,0159 & 52,5714 & 2,023 & 0,045 \\
\hline $\begin{array}{l}\text { To what extent management difficult to } \\
\text { control risk }\end{array}$ & 74,0653 & 63,6508 & 2,649 & 0,009 \\
\hline \multicolumn{5}{|l|}{ Information Risk } \\
\hline $\begin{array}{l}\text { Likelihood of current year material } \\
\text { misstatement }\end{array}$ & 70,8571 & 68,7143 & 0,462 & 0,645 \\
\hline Magnitude of misstatement & 43,1905 & 46,5397 & $-0,586$ & 0,559 \\
\hline Likelihood next year is misstated & 58,1587 & 58,6984 & $-0,108$ & 0,914 \\
\hline \multicolumn{5}{|l|}{ Verification Risk } \\
\hline $\begin{array}{l}\text { Confidence that auditor will detect } \\
\text { misstatements present }\end{array}$ & 73,0635 & 71,8254 & 0,261 & 0,794 \\
\hline $\begin{array}{l}\text { To what extent risk is understood by } \\
\text { auditor }\end{array}$ & 74,1905 & 72,5238 & 0,413 & 0,680 \\
\hline Financial Reporting Risk & 73,3968 & 75,7143 & $-0,567$ & 0,572 \\
\hline
\end{tabular}

The results also show higher familiarity risk, especially in terms of risk immediacy and to what extent management difficult to control risk that experience entity-level material weaknesses compared to companies that experience account-specific material weaknesses. Inconsistency was indicated in this study's results which can be caused by different assignment sequences among those two groups.

The implication of the results of the study shows that information related to material weaknesses at both entity-level and at account-level can also affect investment decision making. This shows that the information submitted by the auditor regarding material weaknesses also has an impact on investment decision making.

\section{Conclusions and Suggestions}

This study aims to examine whether there are differences in risk assessment responses in investment decision making. In this study, accounting students were served as respondents who have followed the subjects of Investment Management and Capital Markets and Financial Statement Analysis as well. The results indicate that the differences in risk response in companies that experience entity-level weakness and account-specific weakness.

Eventually, this study suggests to consider securities analysts and investors as the respondents in the future research. This suggestion is to explore more on response of securities analysts and Investors in 
Indonesia whether they need information other than accounting information, namely information on audit findings on investment decision making.

\section{References}

[1]Almilia, L. S.: Model belief adjustment dalam pengambilan keputusan investasi. Faculty of Economics and Business - Gadjah Mada University Yogyakarta. (2013)

[2]Almilia, L. S., \& Wulanditya, P.: The effect of overconfidence and experience on belief adjustment model in investment judgement. International Research Journal of Business Studies, 9(1): 39 - 47. (2016)

[3]Almilia, L. S., \& Wulanditya P., \& Nita R. A.: The comparison of investment decision frame and belief-adjustment model on investment decision making. Journal of Finance and Banking. 22 (3): $405-$ 417. (2018)

[4]Almilia, L. S., Dewi N. H. U., \& Wulanditya P.: The effect of visualization and complexity task in investment decision making. Holistica - Journal of Business and Public Administration. 10 (1): 68 - 77. (2019)

[5]Ang, N. P., \& Trotman, K. T.: The utilization of quantitative and qualitative information in groups' capital investment decision. Behavioral Research in Accounting. 27(1), 1 - 24. (2015)

[6]Asare, S., \& Wright A.: The effect of change in reporting threshold and type of control deficiency on equity analysts' evaluation of the reliability of future financial statements. Auditing: A Journal of Practice \& Theory 31 (2): 1-17. (2012a)

[7]Asare, S., \& Wright, A.: The effect of type of internal control report on users' confidence in the accompanying financial statement audit report. Contemporary Accounting Research 29 (1): 152-175. (2012b)

[8]Asare, S., B. Fitzgerald, L. Graham, J. Joe, E. N., \& Wolfe C.: Auditors' internal control over financial reporting decisions: Analysis, synthesis and research directions. Auditing: A Journal of Practice \& Theory 32 (Supplement): 131-166. (2013)

[9]Dilla, W. N., Janvrin D. J., \& Jeffrey, C.: The impact of graphical displays of pro forma earnings information on professional and nonprofessional investors' earnings judgments. Behavioral Research in Accounting, 25(1): $37-60$. (2013)

[10]Hogarth, R. M., \& Einhorn H. J.: Order effect in belief updating: the belief - adjustment model. Cognitive Psychology, 24: 1 - 55. (1992)

[11]Rice, S., \& Weber D.: How effective is internal control reporting under SOX 404? Determinants of the (non-) disclosure of existing material weaknesses. Journal of Accounting Research 50 (3): 811-843. (2012)

[12]Tang, F., Hess, T. J., Valacich, J. S., \& Sweeney J. T.: The effect of visualization and interactivity on calibration in financial decision-making. Behavioral Research in Accounting, 26(1), pp. 25 - 58. (2014) 